\title{
Influence of Development of the Organization of the Operational Accounting and Control on the Enterprises' Management of Machine- Building in Ukraine
}

\author{
Olga Starenka
}

\begin{abstract}
:
The article considers the operational management system of machine-building enterprises in Ukraine under the conditions of interpenetration of accounting and control functions and their deep integration due to shift of the control centres with the centres of operational decision-making. It has been proved that control timely influences behaviour and conditions of economic objects using target indicators, norms and regulations, estimates and the data of operational accounting, thus it takes active part in shaping the final results of running the enterprise. This explains its importance in the operational management system. It has been considered that the conditions of economic activity of industrial enterprises are changing intensively under the influence of internal and external factors, which determines the requirement to obtain operational information about the enterprise performance and the achieved results of each department. This is possible due to operational accounting, which must be systemic and cover all business processes, since it influences the functioning of the whole system as the information base for monitoring, and its results constitute the basis for timely decision-making in management. It is proved that well organized system of the accounting and control allows not only to detect in due time shortcomings of the industrial enterprise activity, but also to carry their expeditious elimination out and to prevent their manifestations in the future.
\end{abstract}

Key words: Management; Operational accounting; Operational control.

JEL classification: M41, M42.

\section{Introduction}

The processes of market transformations that takes place in Ukraine requires certain changes in the management of industrial enterprises, and consequently in the organization of accounting and control as its main information systems. Even today, the accounting reforming has not solved the problems of the theory and practice of operational accounting and control. For instance, there is no single point of view regarding the recognition of operational accounting and control.

Some sources indicate that operational accounting is a separate form of economic accounting and has its own goals and objectives (Maksimova, 2014), while other

Olga Starenka; Lecturer, Department of Accounting and Auditing, Odessa National Economic University, Preobrazhenka St. 8, Odessa, 65082, Ukraine; <starenkajaolja@ rambler.ru>. 
Starenka, O.: Influence of development of the organization of the operational accounting and control on the enterprises`management of machine-building in Ukraine.

sources call into question its existence or insist on its full disappearance (Golov, 2007). In recent years the transformation of operational accounting and control in the system of management accounting is increasingly discussed (Plotnichenko, 2011).

Currently single interpretation of these issues has been achieved neither in theory nor in practice yet.

It should be noted that the implementation of operational accounting and control remains simplified and imperfect in many industrial enterprises, which does not allow timely to detect adverse deviations and eliminate them. This, in turn, reduces the efficiency of the enterprise functioning.

Therefore, forming the approach towards further development of operational accounting and control becomes relevant in the modern economic conditions, taking into account the objectives of operational management that will ensure effective functioning of an industrial enterprise.

\section{Background and Methodology}

Theses of local and foreign researchers are devoted to various aspects of the considered problem namely the issues of accounting (Golov, 2007), management accounting (Karpenko, 2005), controlling (Maksimova, 2013), internal control (Maksimova, 2014, Sharovska, 2014.). However, there is a limited number of studies that examine the interrelationship of the functions of operational accounting and control which can contribute to inefficient management decisionmaking.

The objective of article is to prove theoretical bases and to analyse current trends of development of operational accounting and control in system of operational business management

The authors of earlier studies have already made a contribution to studying of this problem. Specifically, they have identified the major trends in the development of operational accounting and control throughout the whole historical period, which are as follows:

1. Operational accounting and control is an objective phenomenon caused by the level of society development and the need for better management of enterprises.

2. The emergence of operational accounting and control are the result of the division of management labour and the development of accounting ideas, when the industrial production growth, the development of the banking system and trading companies could not be satisfied with the information obtained only from accounting, as it did not meet the needs for operational management of the economy. 
European Financial and Accounting Journal, 2015, vol. 10 , no.3, pp. 35-44.

3. Theoretical and methodological principles of operational accounting and control were formed under the influence of scientific ideas.

4. At the present stage of operational accounting and control development, there has been observed some reduction in the sphere of their practical application, the lack of scientific studies and a gap among the theory and methodology and market economy requirements. These facts are caused by the prolonged nature of crisis phenomena on the one hand and the increasing interest both researchers and practitioners to foreign systems of management accounting and control on the other hand.

5. There is an urgent need for a scientific explanation of the place and role of operational accounting and control in the modern management system and improvement of their theory, methodology, organization, and technique (Petrenko, 2010, pp. 8-9).

There is a very close relationship between functions in operational management. In fact, there is the process of their interpenetration or even merging. It is only theoretically that these functions can be considered in isolation and the role of each of them in the process of operational management can be defined.

To represent the activity of industrial enterprises different types of accounting are used. They interact with each other and create a single information system. Previously, operational, statistical and bookkeeping types of accounting were singled out in the system of economic accounting. Then, bookkeeping accounting was subdivided into financial accounting and management accounting. Accounting for tax purposes was pointed out at the same time; it is connected with keeping tax records and preparing tax reports.

If all these types of accounting really exist it is necessary to determine the information that each of them provides for effective management and decisionmaking.

It is clear that the management of an industrial enterprise requires prompt and timely information about the supply of goods and material values, production of goods and their distribution. It can be provided by operational accounting which importance increases under the conditions of market economy.

Statistical accounting is used to obtain information about mass phenomena and processes. To obtain the necessary information statistics uses the data of operational and bookkeeping accounting. Operational and statistical types of accounting do not provide complete and continuous representation of business transactions that cover the entire enterprise business activity. This is the prerogative of bookkeeping accounting.

Thus, all three types of accounting are interrelated; they complement each other and create a unified system of accounting, where operational accounting is the main source of timely information. 

on the enterprises`management of machine-building in Ukraine.

After bookkeeping accounting had been subdivided into financial accounting and management accounting there was much discussion among scholars and practitioners. Today, a certain consensus on these issues has been achieved: firstly, enterprises use financial accounting to represent the information on all the aspects of their activity and use these data to comprise their financial records; secondly, management accounting provides the information for making management decisions within the limits of the enterprise. Accordingly, this information should be timely and reliable; thirdly, accounting for tax purposes uses the information provided by bookkeeping accounting but it also must be timely and reliable.

Thus, we see that each type of accounting should provide timely and accurate information; it is operational accounting that can achieve this. In general, all types of accounting complement each other; each of them considers the same facts of economic activity but from different perspectives.

Since the business environment is constantly changing there is a need in daily information on the status of production, the movement of resources, and the results of each structural unit of the enterprise. Such records are provided by operational accounting which enables operational control of an enterprise (performance of all the activities, the movement of materials, timing of production, product quality, the staff and their qualifications, equipment load, the state of financial calculations, etc.) on a daily basis.

The scientists have been increasingly emphasizing the existence of operational controlling and indicate that the use of controlling in enterprises will help to accomplish information support of decision-making in order to optimize the use of production and other resources, objective assessment of the strengths and weaknesses of the enterprise to achieve the final results (profit, productivity increase, cost reduction, saving resources, etc.). Thus, to achieve this goal it is necessary to systematically use the tools of operational management (Lokchanova, 2014 , p. 3). This indicates that exactly operational information is necessary for carrying out controlling.

Regarding management accounting in recent publications this system is further subdivided into two subsystems: strategic and operational management accounting. The purpose of the first type is to assist in achieving the strategic goals of the enterprise for the benefit of its owners, shareholders, for satisfying the needs of customers and other participants of economic activity (for making strategic management decisions), and the second type is aimed at assisting the management staff in planning, monitoring, and making current management decisions (Plotnichenko, 2011). The use of operational and reliable information can contribute to making management decisions.

The development of accounting in Ukraine is influenced by works of scientists from other countries, who consider theoretical and practical 
European Financial and Accounting Journal, 2015, vol. 10 , no.3, pp. 35-44.

aspects of accounting and control, and this positively affects their organization in our country. But they do not use the concept of operational accounting and control. These concepts are absorbed by more general categories for instance, management accounting.

So Charles T. Horngren and George Foster (2005) specify that "the modern production accounting is often called management accounting as the accountant looks at activity of the enterprise by the head's eyes, and results of managers work often depend on accounting data", that "the production accounting is a management accounting plus small part of the financial accounting ".

Only Anthony R. N. (1999) considering the information for the accounting, notes that the operational information, needed for the constant (daily) accounting, is the registration information that is used for management, financial and tax accounting. But he doesn't call this information the operational accounting.

Thus, operational information, namely the data of operational accounting, is the main information base for any kind of accounting.

Accounting occupies a special place in the system of information support of operational control which cannot exist without accounting information.

There is a very close relationship between them. Accounting creates information conditions for exercising effective control. Accounting data are used to control the industrial and economic activity of enterprises, the implementation of planned targets, and verification of accounting data is provided by means of control. Thus, control is the stage of obtaining information that precedes accounting and the stage that completes the accounting process which, in turn, confirms the existence of feedback.

Control, in its operational mode, should serve as a preventive reaction to objects, mainly to economic processes, and react to them in the current and past modes of time. That is, control with respect to the time of economic operations can be divided into the following types: preventive, current and subsequent. Depending on this one can allocate the goals that must be placed before the control system in each of these modes.

At the initial stage of economic operations, prevention of negative deviations in the managed object should be achieved. The main goal is to prevent the attempts at breaking the law and misusing or wasting funds at the stage of foreseeing and planning, i.e. prior to fulfilling economic operations and financial transactions.

In the course of business operations current control is conducted. Using the data of primary documents, as well as the results of operational and bookkeeping accounting, it is possible to monitor and regulate the economic situation, to prevent losses and damages, and to avoid the implementation of financial offenses, thus exercising preventive regulation of deviations. 
Starenka, O.: Influence of development of the organization of the operational accounting and control on the enterprises`management of machine-building in Ukraine.

Unlike current control, subsequent control is carried out after business transactions. It cannot prevent illegal actions but it allows regulating deviations that have not been found in the process of preventive and current controlling.

All stages of control are important in the management of economic entities, but preventive and current types of control are essentially significant, as they allow to carry out preventive regulation of shortcomings.

It is worth mentioning that due priority should still be given to preventive control, as it is important to prevent deviations in all cases.

All objects of operational management are under the influence of the control function, which should provide the opportunity to exercise and improve the process of management through clear identification of deviations from target goals, rules and regulations, and through interference in the sphere of planning, accounting, and analysis with the purpose of finding deficiencies and disorders that reduce the quality of these functions and have negative impact on the process of management.

These conclusions have real practical value. They direct the authors who are engaged in the development of the operational management system on the interpenetration of accounting and control functions, on their deep integration through shift of the control centres with the centres of operational decision.

The studies of predecessors and our own considerations suggest that control is an independent function of management which secures effective activity of the enterprise and achieving its goals. Using target indicators, norms and regulations, financial estimates and the data of operational accounting, control can affect the behaviour and the state of economic objects, thus actively participating in shaping of the final results of the enterprise. This explains its importance in the system of operational management.

\section{Data, Results and Discussion}

In structure of the industry of the Ukraine the machine building is one of the most important industries, affecting the productivity and efficiency in all areas of economic activity.

The analysis of the index of industrial production dynamics for the period from 2009 to 2013 indicates that in 2009 compared with 2008 a significant decline in production is recorded. In 2010 the situation improved, but the index of industrial production had a value of less then $100 \%$. This indicates the decline of production volumes. Only in 2011 compared to 2010 there was a rapid growth of the industrial production index, it passed the limit of $100 \%$ and reached the maximum level over the period to $127.9 \%$. In 2012 falling was already observed but to an indicator of $103.9 \%$ while in 2013 decrease amplified and made $92.8 \%$. Further 
European Financial and Accounting Journal, 2015, vol. 10 , no.3, pp. 35-44.

decline in production of machine building industry can significantly hurt not only industry but also the economy of the region as a whole.

Tab. 1: Financial results of enterprises of machine building industry in Odessa region in 2013

\begin{tabular}{|c|c|c|c|c|c|}
\hline & \multirow{2}{*}{$\begin{array}{l}\text { Financial results } \\
\text { before taxation, } \\
\text { millions UAH }\end{array}$} & \multicolumn{2}{|c|}{$\begin{array}{l}\text { Enterprises that have } \\
\text { received profit }\end{array}$} & \multicolumn{2}{|c|}{$\begin{array}{l}\text { Enterprises that have } \\
\text { received loss }\end{array}$} \\
\hline & & $\begin{array}{l}\text { As } \% \text { of the } \\
\text { total number of } \\
\text { enterprises }\end{array}$ & $\begin{array}{l}\text { Millions } \\
\text { UAH }\end{array}$ & $\begin{array}{l}\text { As \% of the } \\
\text { total number } \\
\text { of enterprises }\end{array}$ & $\begin{array}{c}\text { Millions } \\
\text { UAH }\end{array}$ \\
\hline \multicolumn{6}{|c|}{2012} \\
\hline \multirow{3}{*}{$\begin{array}{l}\text { Industry } \\
\text { machine } \\
\text { building }\end{array}$} & $-1144,544$ & 63,1 & 754,123 & 36,9 & 1898,667 \\
\hline & 93,726 & 69,8 & 111,096 & 30,2 & 17,370 \\
\hline & \multicolumn{5}{|c|}{2013} \\
\hline Industry & $-1624,338$ & 63,9 & 982,126 & 36,1 & 2606,464 \\
\hline $\begin{array}{l}\text { machine } \\
\text { building }\end{array}$ & 45,817 & 64,2 & 68,762 & 35,8 & 22,945 \\
\hline
\end{tabular}

Source: www.od.ukrstat.gov.ua, authorial computation.

The negative state of the industry is testified by the financial results of the enterprises of machine-building industry of Odessa Region for 2013 presented in the Table 1. It provides background information on the financial results of industrial enterprises in general. Negative financial results for 2013 indicate that the number of enterprises that received loss almost three times more than profitable ones. In comparison with the year 2012 there is a negative trend. Number of unprofitable enterprises as a percentage of total number of enterprises in 2013 increased by $0.9 \%$.

As for the machine building industry the situation is somewhat better. Almost on all kinds of activity the positive financial result is observed before taxation. Number of companies that have received profit exceeds the number of those who have received loss. But in general the industry in comparison with the year 2012 an increase of number of unprofitable enterprises is observed as a percentage to total by $7.8 \%$.

Thus, the negative condition of the machine building industry of the Odessa region was the motive to identify the reasons for this situation, to explore the organization of operational control of enterprises activity.

One of the reasons of such state is that the heads of machine-building enterprises pay insufficient attention to issues relating to the structure of resources. It influences directly on the ability of industry to respond quickly to market demands and receive higher returns that will contribute to their stable functioning.

A significant decline in industrial production and sales was the main cause of the increasing number of enterprises that have received loss from operating activity. 

on the enterprises`management of machine-building in Ukraine.

The main problems that arise in activity of the industrial enterprises are divided into two levels: the level of the state (macro level) and of the enterprise level (micro level). Economic problems arising at the macroeconomic level are the lack of state control over the activities of monopolies and intermediaries, imperfection of the credit mechanism, high level of "shadow" economy operations, imperfect tax system, insufficient development of a market conjuncture, the uncertainty of the economic environment. Regarding the microeconomic level those problems are the lack of effective monitoring, financial control, insufficient solvency of enterprises, obsolescence of fixed assets, the low level of technical upgrade of enterprises, limited domestic demand for domestic products, low innovation activity of domestic enterprises (Goncharenko, 2014).

Our study deals with microeconomic level. On this level one of the main problems is the lack of operational management subsystems in enterprise management system, in particular an effective system of operational accounting and control. This is confirmed by studies of activity of the particular machine building enterprises of Odessa region.

The study of the organization of operational control was carried out on the basis of the inspection, survey and questionnaire of the management, managers of different levels and leading specialists of machine-building enterprises of Odessa region. The results showed that at the surveyed enterprises:

- the scheme of control is not developed;

- many enterprises have no standards, provisions, duty regulations that govern the control conducting;

- only 5 surveyed companies place the control function close to the centres where business processes are carried out directly;

- there are no regulations, that require employees of various departments to carry out the control activities;

- there is no connection between the time of control and economic operations.

Thus, we can conclude that operational control is often spontaneous, that reduces its focus in identification of negative deviations.

Therefore, it must be concluded that the development of operational accounting and control system in management is an absolute necessity to avoid problems of machine-building industry of Ukraine and to promote their further functioning.

Next areas of development of the operational account and control is improvement of standard and legal base which regulates the procedure of their introduction. Further investigation of theoretical and methodological issues concerning the development of operational accounting and control system management. 


\section{Conclusion}

The conditions of economic activity of industrial enterprises have been changing very rapidly nowadays under the influence of internal and external factors. This triggers the necessity to obtain operational information on the state of the enterprise and the work results of each structural unit. This is possible due to operational accounting, which must be systemic and cover all business processes; it influences the functioning of the whole system, as it provides the information basis for control and its results contribute to timely decision-making.

Results of the analysis of the industrial enterprises activity testify that in modern conditions of economic transformations in the country continuous work of the industrial enterprise can be carried out effectively only when its management makes reasonable and timely administrative decisions on the basis of information provided by all structural divisions of the enterprise. Transparency of their work is provided by creation of effective accounting and control system, in particular the prompt.

Introduction of such system is a complex challenge for heads of the industrial enterprises as it is followed by big organizational and structural changes. At the same time its absence provides big risk of receiving unreliable information which can lead to an inefficiency of the enterprise activity. So, well organized system of the accounting and control allows not only to detect in due time shortcomings of the industrial enterprise activity, but also to carry out their expeditious elimination and to prevent their manifestations in the future.

The problems of accounting and control development in the system of operational management now become more relevant for modern enterprises. The existing accounting and control system in management does not give an opportunity to promptly obtain the necessary and relevant information. This may also be due to inadequate automation of the accounting system. And to implement it at a high level, the head must clearly understand what this system has to be and what indicators it has to trace.

Thus, further studies are aimed at analysing and improving the provision of information for accounting and control with subsequent implementation of the innovations in practical activity of enterprises. 
Starenka, O.: Influence of development of the organization of the operational accounting and control on the enterprises`management of machine-building in Ukraine.

\section{References}

Anthony, R. N., Hawkins, D. F., Merchant, K. A., 1999. Accounting, text and cases. New York: Mc Graw- Hill Irwin.

Department of Statistics in the Odessa region. Available from:. <hpp://www.od.ukrstat.gov.ua/>.

Golov, S. F., 2007. Buhgalterskiy oblik v Ukraine: analiz stanu ta perspectivi rozvitku. Kyiv.

Goncharenko, E. N., 2014. Formirovanie mekhanizma ustoychivogo razvitiya predpriyatiya v usloviyakh neopredelennosti ekonomicheskoy sredy. : Dokt, Diss. Odesa, 395.

Horngren, C. T., Foster, G., 2005. Cost Accounting: A Managerial Emphasis / Trans. From Eng. Under the editor Y.V.Sokolova M.: Finance and Statiatics.

Karpenko, O. V., 2005. Upravlinskiy oblik : organizaciya, metedologiya, metodika vikladannya. Poltava.

Lokchanova, N. O., 2014. Ocinka stanu oblikovoi systemi v Ukraini z pozicii concepcii neoinstitucionalizmu. Odesa.

Maksimova, V. F., 2013. Effect udoskonalennya obliky ta kontroly dlya pozitivnoyi dunamiky rozvitku i econimichnoi stabilnosti pidpriemstva. Naukovopraktichniy jurnal "Buhgalterskiy oblik i audit" 9 23-27.

Maksimova, V. F., 2014. Oblik i control v upravlinni economichnoyu stiykistyu pidpriemstv v umovah globalizacii. Odesa.

Petrenko, S. M., 2010. Vnutrishniy control diyalnosti pidpriemstv i yuogo informaciyne zabezpechennya. Kyiv.

Plotnichenko, I. B., 2011. Toeretiko-metodologichni aspekti formuvannya systemy upravlinskogo obliku na promislovih pidrpiemstvah. Lviv, Vydavnytstvo Natsionalnoho universytetu "Lvivska politekhnika" 704,, 57-64.

Sharovska, T., 2014. The internal control system is a key element of management in crisis conditions. Sharovskaya, T. Institutionelle Grundlagen fur die Funktionierung der Okonomik unter den Bedingungen der Transformation: Sammelwerk der wissenschaftlichen Artikel. Verlag SWG imex GmbH, Nurnberg. 